\title{
Finding reviewer for editorial process: A challenge to resolve
}

\author{
Dr. Md. Ashif Iqbal*1
}

\begin{abstract}
AFFILIATION:
1. Dr. Md. Ashif Iqbal

Associate Professor

Dept. of Oral Pathology \& Periodontology

Update Dental College \& Hospital, Dhaka, Bangladesh

Chief Editor, Update Dental College Journal (UpDCJ)
\end{abstract}

Article info.

Received: $2^{\text {nd }}$ March, 2019

Accepted: $15^{\text {th }}$ March, 2019

Volume: 9, Issue-1 April, 2019

DOI: https://doi.org/10.3329/updcj.v9i1.41198

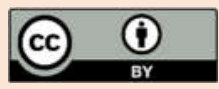

(c) Authors retain copyright and grant the journal right of first publication with the work simultaneously licensed under Creative Commons Attribution License CC - BY 4.0 that allows others to share the work with an acknowledgment of the work's authorship and initial publication in this journal.

https://creativecommons.org/licenses/by/4.0/

Publisher: Update Dental College, Dhaka, Bangladesh

Web: www.updatedentalcollege.edu.bd

E-mail: updcj@hotmail.com

* Corresponding Author

Dr. Md. Ashif Iqbal

Associate Professor

Dept. of Oral Pathology \& Periodontology

Update Dental College \& Hospital, Dhaka, Bangladesh

Chief Editor, Update Dental College Journal (UpDCJ)

Orchid Id: https://orcid.org/0000-0002-9490-7927

Publons: https://publons.com/researcher/1636591/dr-md-ashif-iqbal/

$$
\begin{aligned}
& \text { Researcher Id: } \mathrm{N}-5278-2017 \\
& \text { E-mail: drasif100@gmail.com } \\
& \text { Cell: } 01716116080
\end{aligned}
$$

\section{Citation}

Dr. Md. Ashif Iqbal. Finding reviewers for editorial process: A Challenge to resolve. Update Dental College Journal. 2019 April; 9(1): 1-2

DOI: https://doi.org/10.3329/updcj.v9i1.41198

\section{Introduction:}

Peer review has become significant to the scientific process for over three hundred years. It plays a vital role in funding and publication decisions and in developing the accuracy and transparency of reported published research. Peer review contributes in scientific integrity by helping identify a potent research and weeding out methodologically weak studies. It is still regarded as an essential quality assurance mechanism for funding organizations and journals, and it is the only widely approved method for research validation. It is therefore a deeply entrenched process in high-quality journals.

Reviewers should be experts in the research area that the article describes.

Traditionally they are selected from:

1. Authors publishing in the same field. They are discovered by searching indexes such as PubMed, ArXiv.org, SSRN, or relevant journals.

2. Editorial board.

3. Author choice

However, finding and selection of an ideal reviewer is often challenging for a journal. This editorial, discuss in short regarding this topic, how we could find a reviewer for an article by journal editor.

1. Reviewers can be from the editorial board of a journal, it could be the role of a journal editor or member for initial review regarding article format, Grammar, and referencing system etc. that will less time for actual peer review process.

2. Ask members of the Editorial Board to suggest colleagues or people they know who are publishing or researching in the right field

3. Reviewer could be from the list of authors has been cited in the article

4. Searching authors who have published in the area by using online resources such as Google Scholar, PubMed, Hinari or other indexes.

5. How many times the authors has been cited, is a simple parameter to judge whether the author is well respectable and knowledgeable or not.

6. Reviewer database, Many journals compile a database of reviewer names for their own use. This can be extremely useful, particularly if you identify each person with keywords that indicate their specialty. This will allow you to search for the right person to match submitted articles.

7. One point to remember is that every author that submits to you should be considered as a potential reviewer for a later article. 
8. Publons is one kind of researcher website where more than 500,000 researchers have joined and has given free service for academics to track, verify their peer review and editorial contributions for different academic journals. It was launched in 2012 and adding more than one million reviews across 25,000 journals.

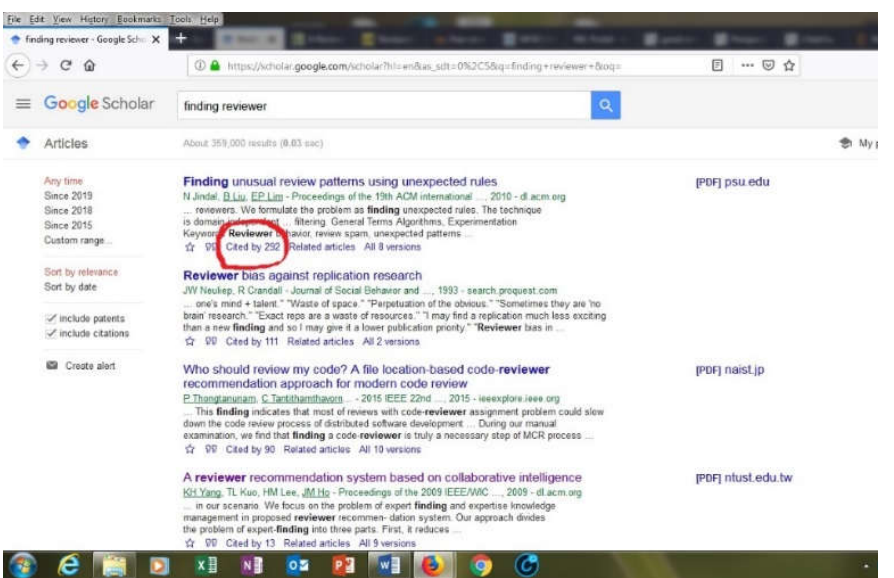

Most of the time reviewer find no benefit after review of an article and loses interest on this field, so a journal committee could enhance the interest by following, that also makes it easy to find out a reviewer.

\section{Accreditation}

Some publishers provide their reviewers with certificates that they can use to prove they have performed reviews. Like The publisher Update Dental College provides letter of Acknowledgment for reviewing article for the Update Dental College Journal (UpDCJ)

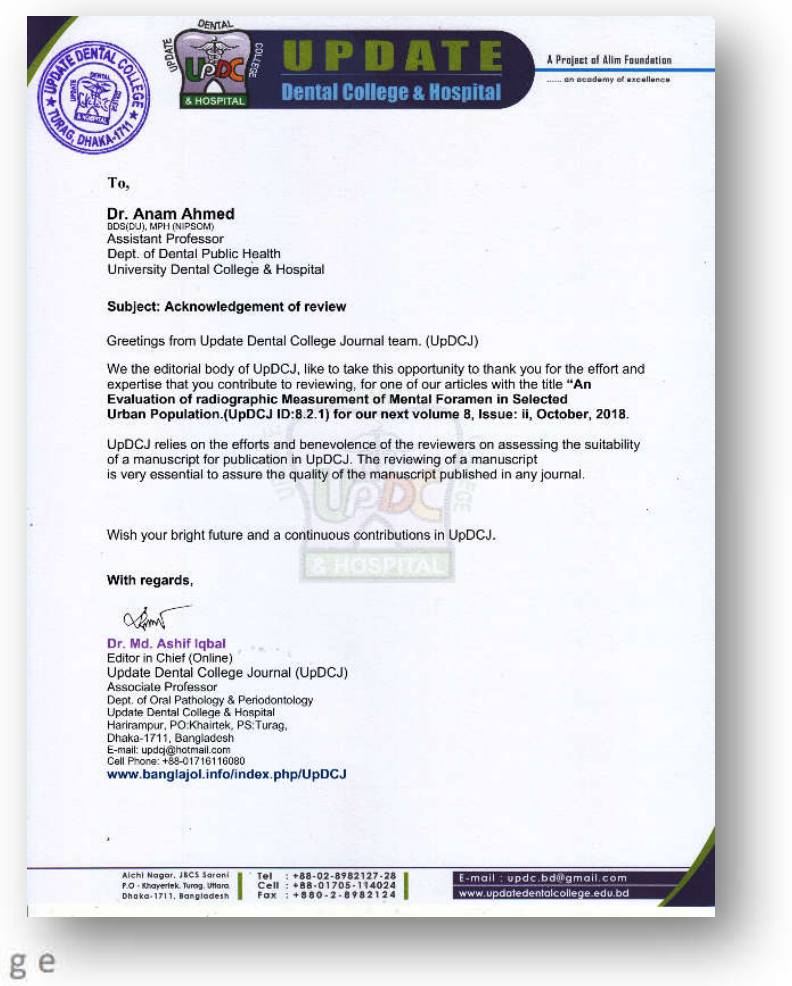

Public thanks and recognition

The most common method used to recognize and thank reviewers is to list all reviewers in the last issue of the year.

This does not identify the articles that they reviewed, but is a means of recognizing and thanking them.

Some journals will go further and invite the top reviewers onto the Editorial Board, to recognize their contribution to the journal.

\section{Initiatives to recognize peer review}

Publons is an international initiative to recognize reviewers. This system uses two methods to add reviews to the profile of an individual:

- Journals partner with Publons, and using an automated linking system deposit proof of review which is then added to the individual's profile page.

- For non-partnering journals, individuals can send the "thank you for reviewing" email for this to be added to their profile.

This is also linked into ORCID (the author identification initiative) so that evidence of reviews is added to ORCID profiles also.

Conclusion:

A reviewer play vital hidden role in the research filed. However, most of the time their work remain undervalue and overlooked. If we the journal committee as well as different national and international authority appreciate all reviewer in different field of professional development, Then most of the researcher will give their time for reviewing an article with their personal interest.

\section{References:}

1. https://moodle.inasp.info/enrol/index.php?id=147

2. Schroter S, Price A, Flemyng E, Demaine A, Elliot J, Harmston RR, Richards $T$, Staniszewska S, Stephens R. Perspectives on involvement in the peerreview process: surveys of patient and public reviewers at two journals. BMJ Open. 2018 Sep 5;8(9):e023357. PubMed PMID: 30185581; PubMed Central PMCID: PMC6129098.

doi: https://doi.org/10.1136/bmjopen-2018-023357

3. Freda, M. C., Kearney, M. H., Baggs, J. G., Broome, M. E., \& Dougherty, $M$. (2009). Peer reviewer training and editor support: results from an international survey of nursing peer reviewers. Journal of Professional Nursing, 25(2), 101-108.

doi: http://doi.org/10.1016/j.profnurs.2008.08.007

4. Gilmore, A., Carson, D., \& Perry, C. (2006). Academic publishing: Best practice for editors, guest editors, authors and reviewers. European business review, 18(6), 468-478. doi: http://dx.doi.org/10.1108/09555340610711094

5. Warne, V. (2016). Rewarding reviewers-sense or sensibility? A Wiley study explained. Learned Publishing, 29(1), 41-50.

doi: http://dx.doi.org/10.1002/leap.1002

6. Willis, M. (2016). Why do peer reviewers decline to review manuscripts? A study of reviewer invitation responses. Learned Publishing, 29(1), 5-7. doi: http://dx.doi.org/10.1002/leap.1006

Website: https://www.banglajol.info/index.php/UpDCJ 